\section{References}

1. Araújo J, Silva GA, Melo FM. Serum prevalence of celiac disease in children and adolescents with type 1 diabetes mellitus. J Pediatr (Rio J). 2006;82:210-14.

2. Mahmud FH, Murray JA, Kudva YC, Zinsmeister AR, Dierkhising RA, Lahr BD, et al. Celiac disease in type 1 diabetes mellitus in a North American community: prevalence, serologic screening and clinical features. Mayo Clin Proc. 2005;80:1429-34.

3. Hill ID, Dirks MH, Liptak GS, Colleti RB, Fasano A, Guandalini S, et al. Guidelines for the diagnosis and treatment of celiac disease in children recommendations of the North American Society for Pediatric Gastroenterology, Hepatology and Nutrition. J Pediatr Gastroenterol Nutr. 2005;40:1-19.

4. Landgraf LF. Prevalência de deficiência de Imunoglobulina " $A$ " em pacientes com diabetes mellitus tipo 1 e sorologia positiva para doença celíaca [dissertação]. Curitiba (PR): Universidade Federal do Paraná; 1999.

5. Liblau RS., Caillat-Zucman S, Fischer AM, Bach JF, Boitard C. The prevalence of selective IgA deficiency in type 1 diabetes mellitus. APMIS. 1992;100:9-12.

6. Cerutti F, Urbino A, Sacchetti C, Palomba E, Zoppo M, Tovo PA. Selective IgA deficiency in juvenile-onset insulin-dependent diabetes mellitus. Pediatr Med Chir. 1998;10:197-201.

7. Baptista $\mathrm{ML}$, Koda $\mathrm{YK}$, Mitsunori $\mathrm{R}$, Nisihara $\mathrm{N}$, Ioshi SO. Prevalence of celiac disease in Brazilian children and adolescents with type 1 diabetes mellitus. J Pediatr Gastroenterol Nutr. 2005;41:621-4.

8. Tanure MG, Silva IN, Bahia M, Penna FJ. Prevalence of celiac disease in Brazilian children with type 1 diabetes mellitus. J Pediatr Gastroenterol Nutr. 2006;42:155-9.

doi:10.2223/JPED.1542

\section{Nelson Rosário}

Professor titular, Universidade Federal do Paraná (UFPR), Curitiba, $\mathrm{PR}$, Brasil.

\section{Loraine Farias Landgraf}

Pediatra. Mestre em Pediatria, UFPR, Curitiba, PR, Brasil. Especialista em Alergia e Imunologia.
In the table where the four Brazilian studies are cited, we observed that the results regarding the frequency of IgA deficiency and of CD among DM-1 patients are similar, since numerical differences are likely to result from methodological factors rather than from actual differences in frequency itself.

We reinforce the final recommendations made by our colleagues: multicenter studies should be conducted in Brazil on the association of $C D$ and $D M-1$ and diabetics should be screened for $C D$ on a routine basis.

\section{Reference}

1. Araújo J, Silva GA, Melo FM. Serum prevalence of celiac disease in children and adolescents with type 1 diabetes mellitus. J Pediatr (Rio J). 2006;82:210-14

doi:10.2223/JPED.1546

\section{Jacqueline Araújo}

Endocrinologista pediatra, Instituto Materno-Infantil de Pernambuco (IMIP) e Hospital das Clínicas, Recife, PE, Brasil. Mestre, Universidade Federal de Pernambuco (UFPE), Recife, PE, Brasil.

\section{Gisélia Alves Pontes da Silva}

Professora adjunta, UFPE, Recife, PE, Brasil. Doutora, Universidade Federal de São Paulo - Escola Paulista de Medicina (UNIFESP-EPM), São Paulo, SP, Brasil.

\section{Francisco Montenegro de Melo}

Professor adjunto, Universidade de Pernambuco (UPE), Recife, PE, Brasil. Mestre, UFPE, Recife, PE, Brasil.

\title{
Pediatrics - research and publications
}

\section{Authors' reply}

To the Editor,

It was with great interest that we read the letter to the editor of Jornal de Pediatria sent by Dr. Loraine Farias Landgraf and Dr. Nelson Rosário, from the Department of Pediatrics of Universidade Federal do Paraná, Brazil, regarding the article "Serum prevalence of celiac disease in children and adolescents with type 1 diabetes mellitus." 1

The comments made by our colleagues are extremely relevant and confirm the findings of our study by pointing out the necessity to measure serum IgA in type 1 diabetes mellitus (DM-1) patients under investigation for celiac disease (CD). This is due to the fact that serological screening using tissue anti-transglutaminase and anti-endomysial antibodies is not appropriate for patients with IgA deficiency.

This is an important concern in population-based studies (of seroprevalence) and in clinical trials, in order to guarantee that the prevalence of $C D$ is not underestimated and that patients with false-negative serological results are further investigated.

\section{Dear Editor}

We were satisfied with the article written by Blank et al., 1 and with the editorial by Marcovitch ${ }^{2}$ in Jornal de Pediatria, which address the growing publication and citation of Brazilian articles in the child and adolescent health field. Between 1990 and 2004, the number of indexed Brazilian articles grew $404 \%$, a figure that exceeds that for the rest of the world $(61 \%)$, and should be a matter for pride and incentive for Brazilian Pediatrics.

However, attention should be paid to the remark by the editor of the BMJ Group, according to whom "Brazilian research in Pediatrics seems healthy," followed by the information that research in clinical pediatrics has recently decreased in the United Kingdom, which might also happen to us. ${ }^{2}$ Some data obtained by Blank et al. also seem to warn against this fact: there was a decrease in the participation of pediatric scientific articles in indexed publications on child and adolescent health. Figure 3 in that article shows a decrease in the percentage of publications regarded by the 
authors in the category "Pediatrics," from 19.7 to $13.5 \%$ in 1993 and 2004, respectively, despite an increase in their number. These data are still more astonishing considering that Jornal de Pediatria, which predominantly publishes articles on clinical themes, was indexed in MEDLINE in that period.

So as to avoid any misinterpretations about these indicators of a decrease in publications in the field of Pediatrics, complementary explanations about other areas, with a better performance between 1993 and 2004, are necessary. By taking a look at Figure 3, what is the origin of "Internal Medicine" articles, whose rate increased from 19.7 to $22.0 \%$ in that period, outnumbering by $50 \%$ the publications of articles in the Pediatrics category? We should also consider the large percentage of articles of unknown origin, referred to as "other areas," comprising 36.4 and $41.0 \%$ of publications indexed in 1993 and 2004, respectively. The decrease in the publication of articles classified in the category "Genetics," from 17.7 to $2.5 \%$ is alarming when we compare both periods, since this area seems to be developing. This detailed information can reveal trends and promising areas of research in the child health field.

If we confirm that clinical research in Brazil has also lost ground as has occurred in the United Kingdom, this is not the result of assessment based on a citation index, as suggested by the editorialist, since these rates have been recently used by the Federal Coordinating Agency for the Improvement of Higher Education (Coordenação de Aperfeiçoamento de Pessoal de Nível Superior, CAPES). The proportional reduction in the publication of articles in the field of clinical pediatrics in indexed journals apparently stems from editorial criteria expounded by Marcovitch ${ }^{2}$ - only well-designed clinical trials are accepted, and there is no place for observational, crosssectional studies, and case series. This has worsened with the increase in the number of submitted papers. ${ }^{3}$ Good-quality clinical research is prospective, requires a large sample, from several clinical services, with efficient organization, financial resources, and time. These studies are comparatively more difficult to undertake than to implement new laboratory methods (e.g.: molecular biology techniques) and experimental studies, in which samples can be more easily obtained, with fewer intervening factors, lower ethical limits and lower costs. All these aspects help to shed some light on what has been going on: laboratory and experimental studies seem to gather evidence with enhanced quality and quickness. This should not weaken the role of clinical experimentation, since it allows applicability to humans. The complementarity of basic and clinical research is quite remarkable, and should progressively increase - from the laboratory bench to the bedside (Translational Medicine). 4

From another standpoint, the possible reduction in the number of publications in clinical pediatrics in indexed journals can result in a productivity gain. The decrease in the amount of publications can be advantageous, provided that we add quality to the articles in relation to diagnosis, treatment, prognosis or risk. Supplanting quantity by quality has been the focus of assessments that use the citation index, as done by Blank et al. The citation index is criticized by many and does not accurately gauge all the qualities of a scientific paper. ${ }^{2}$ However, it indicates the free judgmental value of researchers in the writing of scientific papers on a worldwide basis, and this is certainly not negligible. Well-designed
Brazilian studies, organized by medical societies or by renowned universities and research institutions focusing on important clinical issues are extremely unlikely to be discriminated for publication. There is obvious advantage when a good article answers or raises a question, compared to hundreds of articles that only waste the readers' time. Possibly, we have been taking some steps towards a scenario where the publication of indexed clinical trials decreases, whereas the scientific value is improved.

As addressed in the editorial written by Marcovitch and in the article by Blank et al. there is another role for publications. As only a small portion of original articles are published in indexed journals, generally single-center retrospective studies of lesser originality and/or with small samples are published in non-indexed journals. The existence of these publications and their expansion show that they serve another purpose, which differs from the original scientific development. As editors of one of these publications (Pediatria São Paulo), we have noticed that one of the great purposes of journals lies in the continued education of pediatricians. It seems to be clear that non-indexed journals should not necessarily seek international indexing as a goal, but assess their "impact" on the education of a large number of pediatricians whose priority is patient care. In this regard, case reports, for instance, can be more appealing to clinicians than extensive meta-analyses.

The pioneering article by Blank et al. dealt with a topic that is rarely addressed in an objective fashion in our setting: the production and evolution of research studies/publications about child and adolescent health and, especially, their value. The editorialist, on the other hand, points out to the complexity of such assessment. In effect, there are different impacts - on pediatric science (shown by the citation index) and on the practical activity of pediatricians, quality of life, morbidity and mortality of the population (aspects that are not comprised by the citation rate). In the absence of these assessments, we turn our attention to the number of publications and citations. This is what we can do, but that is not quite enough. It's time to get down to work!

\section{References}

1. Blank D, Rosa LO, Gurgel RQ, Goldani MZ. Brazilian knowledge production in the field of child and adolescent health. J Pediatr (Rio J). 2006;82:97-102.

2. Marcovitch H. A step forward for Brazilian pediatric research. J Pediatr (Rio J). 2006;82:83-5.

3. Procianoy RS. Past, present and future. J Pediatr (Rio J). 2006;82:1.

4. J Transl Med. http://www.translational-medicine.com. Access: 27/09/2006.

doi:10.2223/JPED.1544

\section{Bernardo Ejzenberg}

Professor livre-docente, Faculdade de Medicina, Universidade de São Paulo (USP), São Paulo, SP, Brasil. Membro, Comissão de Pesquisa e Ética, Editor Associado de Pediatria São Paulo. E-mail: bernardoe@icr.hcnet.usp.br

\section{Magda Carneiro-Sampaio}

Professor titular,USP, São Paulo, SP, Brasil. Presidente, Comissão de Pesquisa e Ética, Corpo Editorial de Pediatria São Paulo. Comissão de Pesquisa e Ética, Instituto da Criança, Hospital das Clínicas, Faculdade de Medicina, USP, São Paulo, SP, Brasil. 